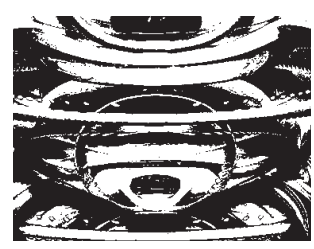

\title{
UČESTALOST NEKIH ASPEKATA PREOTIMANJA PARTNERA I NJIHOVA POVEZANOST SA SOCIOSEKSUALNOSTI
}

\section{Petra GRUNDLER}

Filozofski fakultet, Osijek

Igor KARDUM, Jasna HUDEK-KNEŽEVIĆ

Filozofski fakultet, Rijeka

UDK: $316.728-057.875(497.5): 176.6$

Izvorni znanstveni rad

Primljeno: 17. 1. 2013.

Na uzorku od 819 studenata ispitane su spolne razlike $u$ učestalosti i uspješnosti preotimanja tuđega partnera za kratkotrajnu vezu, učestalosti bivanja objektom preotimanja za kratkotrajnu vezu i uspješnosti takvih pokušaja te učestalosti bivanja žrtvom preotimanja vlastita partnera. Nadalie, ispitani su i odnosi između raznih aspekata preotimanja i socioseksualnosti, posebno na uzorcima žena i muškaraca. Rezultati su pokazali da su muškarci češće od žena pokušali preoteti tuđe partnere za kratkotrajne veze. Sličan broj žena i muškaraca navodi da je u tome bilo donekle uspješno, ali žene češće izjavljuju da su bile prilično uspješne u preotimanju partnera. Podjednak broj žena i muškaraca izjavljuje i da su bili objektom preotimanja, ali značajno veći broj žena navodi da su učestalo bile objektom preotimanja. Uspješnost preotimanja veća je kada je objekt preotimanja muškoga spola. Žene su češće od muškaraca bile u ljubavnoj vezi i češće su bile $u$ vezi s partnerom koji ih je privukao dok su bile u vezi s nekim drugim. Socioseksualnost je kod oba spola slično povezana s iskustvima preotimanja partnera, pri čemu je povezanija s pokušajima nego s uspješnosti preotimanja. Rezultati su objašnjeni evolucijskim teorijama reproduktivnoga ponašanja.

Ključne riječi: preotimanje partnera, kratkotrajne veze, socioseksualnost, evoluciiska teorija

$\triangle \quad$ Igor Kardum, Sveučilište u Rijeci, Filozofski fakultet, Odsjek za psihologiju, Sveučilišna avenija 4, 51000 Rijeka, Hrvatska. E-mail: kardum@ffri.hr 
Tijekom evolucije naših predaka jedan od adaptivnih problema odnosio se na uspješnost privlačenja partnera za romantičnu vezu. Naime, privlačenje poželjnih partnera često je bilo otežano jer su već bili u vezi s drugima. Tako je, primjerice, nedostupnosti žena pogodovala poliginija (Foley, 1996), kao i to što je velik broj mladih djevojaka odmah nakon početka puberteta ulazio u dugotrajne veze (Symons, 1979). Preotimanje partnera odnosi se na ona ponašanja kojima je cilj i namjera privlačenje nekoga za koga je osoba svjesna da je već u vezi s nekim drugim da bi s njim ostvarila kratkotrajnu ili dugotrajnu vezu. Smatra se da je serijska monogamija, česta u raznim kulturama, ponekad rezultat niza preotimanja partnera za dugotrajne veze (Schmitt i Buss, 2001). U osnovi je evolucijskog objašnjenja preotimanja pretpostavka da su osobe koje su se koristile učinkovitijim taktikama privlačenja, pa i preotimanja partnera, imale veću vjerojatnost odabrati poželjnije i prikladnije partnere te tako povećati vlastitu reproduktivnu uspješnost (Schmitt i Buss, 2001). Suvremeni je čovjek naslijedio mehanizme svojih uspješnih predaka, pa je tako i preotimanje partnera jedna od njegovih važnih adaptacija, o čemu svjedoče i neki drugi adaptivni mehanizmi, kao što su ponašanja nadgledanja i zadržavanja partnera (Buss i Shackelford, 1997; Kardum, Hudek-Knežević i Gračanin, 2006).

Iako je teško pouzdano znati koliko je preotimanje bila česta pojava u našoj evolucijskoj prošlosti, istraživanja pokazuju da se u suvremenim lovačko-skupljačkim zajednicama, koje su najsličnije onima iz naše evolucijske prošlosti, preotimanje partnera događa relativno često. Istraživanja u suvremenim zapadnim društvima pokazuju da se izvanbračne nevjere kao jedan od oblika preotimanja partnera javljaju u 20-50\% brakova (npr. Wiederman, 1997). U skladu s evolucijskom teorijom, učestalost preotimanja partnera trebala bi se razlikovati s obzirom na spol preotimača i preotete osobe te vremenski aspekt preotimanja (preotimanje za kratkotrajnu vezu nasuprot dugotrajnoj vezi). Naime, prema teoriji diferencijalnoga roditeljskog ulaganja (Trivers, 1972), muškarci su skloniji preotimanju većega broja partnerica za kratkotrajne veze, jer im takvo ponašanje osigurava reproduktivni uspjeh bez većeg ulaganja u potomstvo, posebno ako će o potomcima skrbiti drugi muškarac, stalni partner privremeno preotete žene. Kada traže kratkotrajne veze, muškarci su manje izbirljivi od žena, jer im neselektivnost omogućuje veći broj partnerica i reproduktivne dobitke, premda su mnogo izbirljiviji kada je posrijedi dugotrajna veza (Kenrick, Sadalla, Groth i Trost, 1990). S druge strane, zbog ograničenijih reproduktivnih resursa, žene su u odabiru partnera izbirljivije od muškaraca. Premda temelje- 
DRUŠ. ISTRAŽ. ZAGREB GOD. 22 (2013), BR. 1 STR. $63-78$

GRUNDLER, P., KARDUM I., HUDEK-KNEŽEVIĆ, J.: ÚČESTALOST NEKIH... ni na subjektivnim procjenama, empirijski podaci doista pokazuju da muškarci češće pokušavaju preoteti tuđe partnerice te da ih je lakše preoteti. Tako npr. istraživanje na relativno malom uzorku američkih studenata pokazuje da $64 \%$ muškaraca i $49 \%$ žena izjavljuje kako su pokušali preoteti partnera za kratkotrajnu vezu, 95\% muškaraca i $91 \%$ žena izjavljuje da ih je nekada netko pokušao preoteti za kratkotrajnu vezu, $86 \%$ muškaraca i $85 \%$ žena izjavljuje da je nekada netko pokušao preoteti njihova partnera za kratkotrajnu vezu te $50 \%$ muškaraca i $35 \%$ žena tvrdi da je bilo uspješno preoteto od prethodnoga partnera (Schmitt i Buss, 2001). U međukulturnom istraživanju provedenom u 53 zemlje, Schmitt i suradnici (2004) nalaze da je u 10 svjetskih regija prosječno $56,9 \%$ muškaraca i 34,9\% žena nekada pokušalo preoteti partnera za kratkotrajnu vezu, 69,1\% muškaraca i 71,3\% žena nekada netko pokušao preoteti za kratkotrajnu vezu, $83,2 \%$ muškaraca i 83,3\% žena nekada uspješno preotelo partnera za kratkotrajnu vezu, dok $63,2 \%$ muškaraca i $45,0 \%$ žena izjavljuje da je nekada bilo uspješno preoteto od prethodnoga partnera.

Iako žene češće preotimaju partnere da bi ostvarile dugotrajnu vezu, kada žele preoteti muškarca za kratkotrajnu ve$\mathrm{zu}$, obično su motivirane brzim stjecanjem resursa, jer muškarci više ulažu u ženu na početku veze (Buss i Schmitt, 1993). Nakon kratkotrajne veze, one često nastavljaju svoju dotadašnju dugotrajnu vezu, što prema nekim procjenama dovodi do toga da u raznim kulturama čak i do $10 \%$ djece nisu biološka djeca očeva za koje se pretpostavlja da jesu (Baker i Bellis, 1995). Uz to, u kratkotrajne veze žene češće ulaze s muškarcima koji su tjelesno simetričniji i privlačniji od njihova trenutačnog dugotrajnog partnera. To je vjerojatno posljedica preferencije žena prema tzv. "kvalitetnim genima" muškaraca, što pridonosi kvaliteti njihova potomstva, a time i njihovoj reproduktivnoj uspješnosti (Gangestad i Thornhill, 1997; Schmitt i Buss, 2001; Schmitt i Shackelford, 2003).

Izrazita socijalna nepoželjnost preotimanja, koje ljudi najčešće taje i izbjegavaju o njemu otvoreno govoriti, znatno otežava njegovo ispitivanje. Međutim, važnost ispitivanja i razumijevanja mehanizama u osnovi je u tome što je ono često praćeno nasiljem zbog osvete, socijalnim odbacivanjem, ljubomorom, prekidom veza, razvodom i sl. (Buss, 2002; Platek i Shackelford, 2006).

Istraživanja pokazuju da postoje neke razlike u individualnim karakteristikama osoba s obzirom na različite aspekte preotimanja. Tako su npr. osobe koje su sklonije preotimanju manje ugodne i savjesne, a one koje drugi pokušavaju preoteti ekstravertiranije i otvorenije (Schmitt i Buss, 2001). Međutim, treba napomenuti da su općenito interindividualne razlike povezane s pokušajima i uspješnosti preotimanja rela- 
DRUŠ. ISTRAŽ. ZAGREB GOD. 22 (2013), BR. 1, STR. 63-78

GRUNDLER, P., KARDUM I., HUDEK-KNEŽEVIĆ, J.: ÜČESTALOST NEKIH... tivno slabo poznate. Jedna potencijalno važna karakteristika u kontekstu preotimanja mogla bi biti socioseksualnost. Ona se odnosi na interindividualne razlike u spremnosti ulaženja $\mathrm{u}$ seksualne odnose bez prethodnoga emocionalnog vezivanja, bliskosti i predanosti drugoj osobi (Snyder, Simpson i Gangestad, 1986). Osobe kojima treba relativno više vremena, vezanosti, predanosti vezi i bliskosti s heteroseksualnim partnerom prije no što su spremne upustiti se $\mathrm{u}$ seksualni odnos nazivaju se restriktivnima, dok se one koje zahtijevaju manje vremena, vezanosti, predanosti i bliskosti nazivaju nerestriktivnima.

Cilj je ovoga istraživanja bio ispitati spolne razlike na uzorku studenata $\mathrm{u}$ učestalosti i uspješnosti preotimanja tuđega partnera za kratkotrajnu vezu, učestalosti bivanja objektom preotimanja za kratkotrajnu vezu i uspješnosti takvih pokušaja te učestalosti bivanja žrtvom preotimanja vlastita partnera za kratkotrajnu vezu. Ispitane su i veze navedenih iskustava preotimanja partnera sa socioekonomskim statusom sudionika te sa socioseksualnosti, posebno na uzorcima žena i muškaraca.

U skladu s evolucijskom teorijom i dosadašnjim nalazima može se pretpostaviti da će muškarci češće pokušavati preotimati partnere za kratkotrajne veze, da će žene biti uspješnije u preotimanju partnera $\mathrm{i}$ da će češće biti objektom preotimanja, dok će muškarci biti uspješnije preotimani. Može se pretpostaviti i da će žene češće biti u dugotrajnoj vezi s partnerom koji ih je preoteo. Viši socioekonomski status, pogotovo muškaraca, trebao bi biti povezan s više pokušaja i većom uspješnosti preotimanja partnera te češćim bivanjem objektom preotimanja. Nadalje, očekuje se da će viša socioseksualnost osobe biti pozitivno povezana s pokušajima preotimanja, učestalosti bivanja objektom preotimanja te s uspješnosti drugih da je preotmu.

\section{METODA}

\section{Sudionici i postupak}

U istraživanju je sudjelovalo 819 studenata raznih fakulteta Sveučilišta J. J. Strossmayer u Osijeku (N=418) (22,2\% s Filozofskoga fakulteta, 14,1\% s Ekonomskoga fakulteta, 12,4\% s Pravnoga fakulteta, 28,0\% s Elektrotehničkoga fakulteta, 10,0\% s Učiteljskoga fakulteta i 10,5\% s Građevinskoga fakulteta) i Sveučilišta u Rijeci (N=401) (24,3\% s Filozofskoga fakulteta, 16,2\% s Ekonomskoga fakulteta, 13,1\% s Pravnoga fakulteta, 25,5\% s Tehničkoga fakulteta, 15,3\% s Pomorskoga fakulteta i 5,6\% s Građevinskoga fakulteta). Ukupno je sudjelovalo 400 (48,96\%) muškaraca i $419(51,04 \%)$ žena od 18 do 25 godina. Prosječna 
DRUŠ. ISTRAŽ. ZAGREB GOD. 22 (2013), BR. 1 STR. $63-78$

GRUNDLER, P., KARDUM I., HUDEK-KNEŽEVIĆ, J.: ÚČESTALOST NEKIH...

\section{Instrumenti}

a sudionika $21,16(\mathrm{SD}=1,96)(\mathrm{t}=3,13 ; \mathrm{p}=0,002 ; \mathrm{d}=0,22)$. Ispodprosječni socioekonomski status imalo je $9,3 \%$ sudionika, prosječni $74,6 \%$, a iznadprosječni $16,1 \%$. Ispitivanje je bilo anonimno i dobrovoljno, a provedeno je grupno u terminima održavanja redovite nastave.

Za mjerenje učestalosti i uspješnosti preotimanja partnera upotrijebljen je Upitnik romantične privlačnosti (Anonymous Romantic Attraction Survey - ARAS, Schmitt i Buss, 2001). Upitnik se sastoji od 10 pitanja koja se odnose na prijašnja iskustva $u$ preotimanju partnera za kratkotrajne veze. Prvih pet čestica ispituje učestalost pokušaja preotimanja partnera te učestalost bivanja žrtvom i objektom preotimanja partnera, kao i uspješnost $\mathrm{u}$ tim ponašanjima. Odgovora se na ljestvici od 7 stupnjeva (1 - nikad, odnosno potpuno neuspješan; 7 - uvijek, odnosno vrlo uspješan). Preostalim se trima analiziranim česticama ispituje je li sudionik trenutačno u ljubavnoj vezi, je li u vezi s partnerom kojeg je privukao/koji je njega privukao dok je bio u vezi s nekim drugim. Zbog maloga broja odgovora nisu analizirane dvije čestice koje ispituju odnos između bivšega i sadašnjega partnera (ukupno je odgovorilo $10,5 \%$ ispitanika, od kojih 81,4\% navodi odgovor "stranac") te odnos između ispitanika i prethodnoga partnera kojeg je privukao dok je bio u vezi s nekim drugim (ukupno je odgovorilo $11,8 \%$ ispitanika, od kojih $74,2 \%$ navodi odgovor "stranac").

Socioseksualnost je mjerena hrvatskom verzijom (Kardum, Gračanin i Hudek-Knežević, 2006) Upitnika socioseksualne orijentacije (Sociosexual Orientation Inventory, SOI, Simpson i Gangestad, 1991). Upitnik se sastoji od 7 čestica na kojima ispitanici procjenjuju svoje stvarno seksualno ponašanje (npr. "S koliko ste partnera imali seksualni odnos u proteklih godinu dana?"), zatim čestinu misli o seksualnom ponašanju (npr. "Koliko često zamišljate seksualni odnos s nekom drugom osobom koja nije Vaš trenutačni partner?") te stavove prema usputnom seksu (npr. "Mogu zamisliti da mi je ugodno i da uživam u usputnom seksu s više partnera."). Format skala procjena različit je kod pojedinih čestica, pa se zbog toga ukupan rezultat izražava kao ponderirana suma (vidi opširnije u Simpson i Gangestad, 1991). Viši ukupni rezultat na ovom upitniku odražava nerestriktivniju socioseksualnost. Većina prethodnih istraživanja pokazuje da je ova mjera jednodimenzionalna i da ima adekvatnu konvergentnu i diskriminantnu valjanost, iako postoje i nalazi koji ne govore u prilog njezinoj jednodimenzionalnosti (Webster i Bryan, 2007). Test-retest pouzdanost $u$ razmaku od 2 mjeseca bila je 0,94 , a pouzdanost unutarnje 
DRUŠ. ISTRAŽ. ZAGREB GOD. 22 (2013), BR. 1, STR. 63-78

GRUNDLER, P., KARDUM I., HUDEK-KNEŽEVIĆ, J.: ÜČESTALOST NEKIH...

\section{REZULTATI}

konzistencije (Cronbach-alpha) 0,73 (Simpson i Gangestad, 1991). Na uzorku sudionica ovoga istraživanja pouzdanost unutarnje konzistencije (Cronbach-alpha) iznosila je 0,80, na uzorku sudionika 0,73 , a na ukupnom uzorku 0,77 . Prosječna vrijednost svih sudionika ovoga istraživanja iznosi 39,29 (SD=33,26). Na ovom upitniku muškarci obično postižu značajno više vrijednosti. Prosječna vrijednost koju postižu sudionici ovoga istraživanja iznosi $45,80(\mathrm{SD}=40,84)$, a sudionice $33,06(\mathrm{SD}=22,19)$ $(t=5,31 ; p<0,001 ; d=0,39)$. Prosječna vrijednost koju postižu muškarci u ovom istraživanju vrlo je slična prosječnoj vrijednosti dobivenoj na velikom uzorku sudionika iz 48 zemalja $(\mathrm{M}=46,67)$, dok je prosječna vrijednost žena u ovom istraživanju nešto viša od prosječne vrijednosti koje postižu žene $u$ prethodno spomenutom istraživanju $(M=27,34)$ (vidi opširnije u Schmitt, 2005).

Nadalje, jednom su česticom sudionici procijenili svoj socioekonomski status izabirući jedan od tri odgovora: ispodprosječan, prosječan ili iznadprosječan.

Da bi podaci dobiveni Upitnikom romantične privlačnosti bili usporedivi, obrađeni su strategijom koju su predložili Schmitt i Buss (2001). Za svako od prvih 5 pitanja upitnika izračunani su postoci odgovora, posebno za ispitanike $i$ za ispitanice. $U$ pitanjima koja se odnose na učestalost pokušaja preotimanja partnera svi odgovori veći od 1 smatrani su nekim iskustvom, a odgovori veći od 5 učestalim iskustvom preotimanja partnera. U pitanjima o uspješnosti pokušaja preotimanja partnera svi odgovori veći od 1 smatrani su donekle uspješnim, dok su odgovori veći od 5 smatrani prilično uspješnim preotimanjem partnera (Schmitt i Buss, 2001). Spolne razlike u učestalosti i uspješnosti preotimanja partnera izračunane su hi-kvadrat testom. Najprije su uspoređeni ispitanici bez iskustva preotimanja s onima koji su imali neko iskustvo, odnosno potpuno neuspješni s donekle uspješnima. Nakon toga, uspoređeni su ispitanici s čestim iskustvom preotimanja, odnosno oni koji su bili prilično uspješni sa svim ostalim ispitanicima. Rezultati tih analiza prikazani su u Tablici 1.

Od ukupnoga broja ispitanika koji su odgovorili na pitanje "Jeste li ikada pokušali privući nekoga tko je tada već bio u ljubavnoj vezi s nekim drugim da biste s njim ostvarili kratkotrajnu seksualnu vezu?" 54,6\% (N=446) izjavilo je da je imalo neko iskustvo, a samo 7,6\% ( $\mathrm{N}=62)$ da je imalo učestalo iskustvo preotimanja partnera. Neko iskustvo preotimanja partnera statistički je značajno češće kod muškaraca nego kod žena. Minimalna veličina efekta izražena $\varphi$ koeficijentom koja se može smatrati praktički značajnom iznosi 0,20 , umjerena 
(1) TABLICA

Postoci pojedinih kategorija odgovora

spolne razlike $u$

iskustvima vezanim za

preotimanje partnera
0,50, a snažna 0,80 i više (Ferguson, 2009). Dakle, razlika između muškaraca i žena u nekom iskustvu preotimanja, iako statistički značajna, u ovom se istraživanju može smatrati relativno malom. Nadalje, muškarci su statistički značajno češće nego žene imali učestala iskustva preotimanja partnera, međutim veličina tog efekta vrlo je niska.

\begin{tabular}{|c|c|c|c|c|c|c|c|c|}
\hline \multirow[b]{2}{*}{ Iskustva preotimanja partnera } & \multicolumn{4}{|c|}{ Ikada/donekle } & \multicolumn{4}{|c|}{ Često/prilično } \\
\hline & $\mathrm{M} \%$ & Ž\% & $\chi^{2}$ & $\varphi$ & $\mathrm{M} \%$ & Ž\% & $\chi^{2}$ & $\varphi$ \\
\hline Pokušali preoteti nekoga & 67,7 & 42,0 & $54,75^{* *}$ & 0,26 & 11,6 & 3,8 & $17,10^{* *}$ & 0,15 \\
\hline Uspješno preoteli nekoga & 87,5 & 86,2 & 0,15 & 0,02 & 28,1 & 55,1 & $30,84^{* *}$ & 0,27 \\
\hline Netko vama pokušao & & & & & & & & \\
\hline preoteti partnera & 72,4 & 70,8 & 0,27 & 0,02 & 12,2 & 10,6 & 0,47 & 0,02 \\
\hline Netko vas pokušao preoteti & 84,9 & 82,3 & 1,03 & 0,04 & 13,9 & 27,6 & $23,18^{* *}$ & 0,17 \\
\hline Netko vas uspješno preoteo & 57,0 & 38,1 & $22,94^{* *}$ & 0,19 & 12,6 & 6,3 & $7,82^{*}$ & 0,11 \\
\hline
\end{tabular}

${ }^{* *} \mathrm{p}<0,01 ;{ }^{*} \mathrm{p}<0,05 ; \varphi$ - fi koeficijent korelacije; $\chi^{2}$ - hi-kvadrat test; $\mathrm{M}$ - muškarci; $\check{Z}$ - žene

Od ispitanika koji su imali neko iskustvo preotimanja, 87\% $(\mathrm{N}=374)$ na pitanje "Ako ste ikada pokušali privući nekoga tko je već bio u ljubavnoj vezi s nekim drugim, s namjerom da s njim ostvarite kratkotrajnu seksualnu vezu, koliko ste u tome bili uspješni?" odgovorilo je da su bili donekle, dok je $39,1 \%(N=168)$ smatralo sebe prilično uspješnima u preotimanju partnera.

Razlika između muškaraca i žena u donekle uspješnom preotimanju partnera nije statistički značajna. Međutim, žene statistički značajno češće smatraju da su one prilično uspješne u preotimanja partnera, pri čemu je veličina tog efekta mala.

Na pitanje "Dok ste bili u ljubavnoj vezi, je li ikada itko pokušao odvući Vašega partnera s namjerom da s njim ostvari kratkotrajnu seksualnu vezu?" 71,6\% (N=579) ispitanika izjavilo je da je nekada netko njima pokušao preoteti partnera, a $11,4 \%(\mathrm{~N}=92)$ da su imali često iskustvo da im je netko pokušao preoteti partnera. Nema značajne razlike između muškaraca i žena ni kada se radi o nekom ni kada se radi o učestalom iskustvu pokušaja da im netko preotme partera.

Većina ispitanika $(83,5 \%$; $N=680)$ na pitanje "Kada ste bili u ljubavnoj vezi, je li Vas ikada itko pokušao odvući od Vašega ljubavnog partnera s namjerom da s Vama ostvari kratkotrajnu seksualnu vezu?" izjavila je da ih je nekada netko pokušao preoteti od njihovog partnera, dok je tek 20,9\% $(\mathrm{N}=170)$ izjavilo da su to događalo učestalo. Između muškaraca i žena nije bilo značajne razlike $\mathrm{u}$ nekom iskustvu bivanja objektom pokušaja preotimanja, no žene su značajno češće izjavljivale da su učestalo bile objektom pokušaja preotimanja. Ta se razlika također može smatrati malom. 
DRUŠ. ISTRAŽ. ZAGREB GOD. 22 (2013), BR. 1, STR. 63-78

GRUNDLER, P., KARDUM I., HUDEK-KNEŽEVIĆ, J.: ÜČESTALOST NEKIH...

(1) TABLICA 2

Postoci odgovora DA i spolne razlike po pojedinim pitanjima
Od onih ispitanika koji su bili objekti preotimanja, 47,3\% $(\mathrm{N}=308)$ na pitanje "Ako Vas je netko pokušao privući kao partnera za kratkotrajnu seksualnu vezu dok ste bili u ljubavnoj vezi, koliko je u tome bio uspješan?" odgovorilo je da su njihovi otimači bili donekle, a 9,4\% $(\mathrm{N}=61)$ da su bili prilično uspješni u preotimanju. I kada se radilo o nekakvom i kada se radilo o znatnom uspjehu, preotimanje je bilo statistički značajno uspješnije kada su preotimani muškarci, ali su u oba slučaja ti efekti vrlo mali.

Ispitani su i odnosi između pojedinih pitanja upitnika romantične privlačnosti, posebno za ispitanike i ispitanice. Rezultati pokazuju postojanje niskih do umjerenih korelacija između pojedinih aspekata preotimanja i kod žena (od 0,07 do 0,46 ) i kod muškaraca (od -0,01 do 0,46). Najviša povezanost i kod muškaraca i kod žena jest između pokušaja da netko sudioniku preotme partnera i pokušaja da netko drugi preotme sudionika $(0,46 ; p<0,001 ;$ i kod žena i kod muškaraca). Povezanost između sudionikove čestine i uspješnosti pokušaja preotimanja drugih kod žena iznosi $0,39(\mathrm{p}<0,001)$, a kod muškaraca $0,27(p<0,001)$, dok povezanost između čestine i uspješnosti kojom su drugi preoteli sudionika kod žena iznosi $0,25(\mathrm{p}<0,001)$, a kod muškaraca $0,22(\mathrm{p}<0,001)$.

U Tablici 2 prikazani su postoci slaganja s pojedinim pitanjima koja se odnose na trenutačnu ljubavnu vezu i njezin odnos s preotimanjem te spolne razlike.

\begin{tabular}{lrrrr}
\hline Trenutačna veza i preotimanje & $\mathrm{M} \%$ & Ž\% & $\chi^{2}$ & $\varphi$ \\
\hline $\begin{array}{l}\text { Jeste li trenutačno u ljubavnoj vezi? } \\
\begin{array}{l}\text { Jeste li trenutačno u ljubavnoj vezi s partnerom kojeg } \\
\text { ste privukli dok je bio u vezi s nekim drugim? }\end{array}\end{array}$ & 50,3 & 63,2 & $13,57^{* *}$ & 0,13 \\
$\begin{array}{l}\text { Jeste li trenutačno u ljubavnoj vezi s partnerom koji je } \\
\text { vas privukao dok ste bili u vezi s nekim drugim? }\end{array}$ & 15,9 & 12,5 & 0,87 & 0,05 \\
& 12,6 & 22,7 & $7,16^{* *}$ & 0,13
\end{tabular}

${ }^{*} \mathrm{p}<0,01 ;{ }^{*} \mathrm{p}<0,05 ; \varphi$ - fi koeficijent korelacije; $\chi^{2}$ - hi-kvadrat test; $\mathrm{M}$ - muškarci; $\check{Z}$ - žene

U vrijeme ispitivanja 56,9\% ( $\mathrm{N}=466)$ sudionika bilo je $\mathrm{u}$ ljubavnoj vezi, od toga $13,9 \%(\mathrm{~N}=65)$ u vezi s nekim koga su privukli dok je bio $u$ vezi s drugom osobom, a 18,4\% ( $\mathrm{N}=85)$ s nekim tko je njih privukao dok su bili u vezi s drugim partnerom. Žene su češće nego muškarci u vrijeme ispitivanja bile u ljubavnoj vezi i češće su bile u vezi s partnerom koji ih je privukao dok su bile u vezi s nekim drugim, međutim, ovi su efekti vrlo mali. U vrijeme ispitivanja žene i muškarci nisu se razlikovali u čestini ljubavnih veza s osobom koju su privukli dok je bila u vezi s nekim drugim. Treba napomenuti da više od $90 \%$ sudionika svoje ljubavne veze s partnerom kojeg su privukli dok je bio u vezi s nekim drugim ili koji je njih pri- 
DRUŠ. ISTRAŽ. ZAGREB GOD. 22 (2013), BR. 1 STR. 63-78

GRUNDLER, P., KARDUM I., HUDEK-KNEŽEVIĆ, J.: UUČESTALOST NEKIH...

$\rightarrow$ TABLICA 3

Povezanost raznih aspekata preotimanja sa socioseksualnosti žena i muškaraca
Odnos socioekonomskoga statusa i spola s raznim aspektima preotimanja partnera ispitan je dvosmjernom analizom varijance (3x2), pri čemu su socioekonomski status i spol bili nezavisne, a aspekti preotimanja zavisne varijable. Nije dobivena ni jedna interakcija socioekonomskoga statusa i spola, a jedini značajni glavni efekt socioekonomskoga statusa dobiven je za uspješnost preotimanja partnera $(F=4,55 ; \mathrm{p}=0,011$; parcijalna $\left.\eta^{2}=0,02\right)$. Tukeyev HSD-test pokazuje da se osobe iznadprosječnoga socioekonomskog statusa procjenjuju značajno uspješnijima od onih prosječnoga statusa $(p=0,044)$. U Tablici 3 prikazane su povezanosti raznih aspekata preotimanja sa socioseksualnosti žena i muškaraca.

\begin{tabular}{lll}
\hline Iskustva preotimanja partnera & Žene & Muškarci \\
\hline Pokušali preoteti nekoga & $0,24^{* *}$ & $0,29^{* *}$ \\
Uspješno preoteli nekoga & 0,11 & 0,10 \\
Netko vama pokušao preoteti partnera & 0,06 & $0,11^{*}$ \\
Netko vas pokušao preoteti & $0,26^{* *}$ & $0,21^{* *}$ \\
Netko vas uspješno preoteo & $0,14^{*}$ & $0,19^{* *}$
\end{tabular}

${ }^{* *} \mathrm{p}<0,01 ;{ }^{*} \mathrm{p}<0,05$

Iskustva preotimanja partnera slično su povezana sa socioseksualnosti i kod žena i kod muškaraca. Kod oba spola ona je najviše povezana s pokušajima ispitanika da preotmu tuđe partnere i s pokušajima drugih da preotmu ispitanike te $\mathrm{u}$ nešto manjoj mjeri s uspješnosti drugih da preotmu ispitanike. Samo kod muškaraca socioseksualnost je značajno povezana s pokušajima drugih da ispitanicima preotmu partnera.

\section{RASPRAVA}

Rezultati ovoga istraživanja pokazali su da su muškarci češće od žena pokušali preoteti tuđe partnere za kratkotrajne veze (Tablica 1). Oko 68\% muškaraca i $42 \%$ žena barem je nekada pokušalo privući drugu osobu za koju su znali da je u vezi s nekim drugim. Sličan postotak muškaraca i žena (oko 87\%) navodi da je u tome bilo donekle uspješno, međutim žene češće izjavljuju da su bile prilično uspješne u preotimanju partnera. Većina ispitanika, oko $70 \%$ muškaraca i isto toliko žena, izjavilo je da im je nekada netko pokušao preoteti partnera. Sličan postotak i muškaraca i žena (iznad $80 \%$ ) izjavljuje da ih je netko nekada pokušao preoteti, ali značajno veći postotak žena navodi da su učestalo bile mete preotimanja. Uspješnost preotimanja muškaraca značajno je veća nego uspješnost preotimanja žena. Veličine efekata uglavnom su male, međutim potvrđene su hipoteze da su muškarci skloniji kratkotrajnim vezama nego žene, da će žene biti uspješnije u preotimanju i 
DRUŠ. ISTRAŽ. ZAGREB GOD. 22 (2013), BR. 1, STR. 63-78

GRUNDLER, P., KARDUM I., HUDEK-KNEŽEVIĆ, J.: ÜČESTALOST NEKIH... češći objekti preotimanja nego muškarci te da će muškarci biti uspješnije preotimani nego žene. Slični su rezultati dobiveni u dva prethodno navedena istraživanja (Schmitt i Buss, 2001; Schmitt i sur., 2004), pa je ovo istraživanje još jedna potvrda da su učestalost i uspješnost preotimanja partnera za kratkotrajne veze te spolne razlike $\mathrm{u}$ tim ponašanjima univerzalne. Iako su dobivene veličine efekata male, one na populacijskoj razini mogu biti vrlo značajne ako su obilježja koja pridonose učestalosti i uspješnosti preotimanja partnera heritabilne te ako dovode barem do minimalnih razlika u reproduktivnoj uspješnosti (Futuyma, 2009).

Rezultati ovoga istraživanja mogu se promatrati u kontekstu razlika u reproduktivnoj biologiji muškaraca i žena, čije posljedice detaljnije elaborira teorija diferencijalnoga roditeljskog ulaganja (Trivers, 1972). Muškarci mogu lakše povećati svoju reproduktivnu uspješnost većim brojem kratkotrajnih veza jer manje ulažu u svakoga pojedinog potomka nego žene, pa stoga imaju manja ograničenja vezana uz moguće dodatno potomstvo s drugim ženama. Dakle, njihovi su reproduktivni resursi manje ograničeni, pa se zbog toga njihova ukupna reproduktivna uspješnost može povećati ako imaju pristup većem broju žena.

$\mathrm{S}$ druge strane, žene su izbirljivije $\mathrm{u}$ odabiru partnera jer više ulažu u potomstvo nego muškarci i potencijalno više gube od svakoga dodatnog uparivanja. Međutim, rezultati ovoga, kao i nekih prethodnih, istraživanja (Buss i Schmidt, 1993) pokazuju da su žene, iako manje nego muškarci, također sklone kratkotrajnim vezama. Naime, evolucijska objašnjenja distalnih uzroka sklonosti žena prema kratkotrajnim vezama naglašavaju da one njima mogu ostvariti neke značajne reproduktivne dobitke kao što su hrana ili zaštita, kvalitetniji genetski materijal potomaka, genetsku različitost među potomstvom itd. (Geary, 1998), ali i da kratkotrajne veze mogu poslužiti u uspostavljanju razine aspiracije kod odabira partnera za dugotrajnu vezu (Miller i Todd, 1998). Navedeni su procesi doveli do sustava uparivanja u kojem su oba spola, a osobito muškarci, skloni kratkotrajnim vezama te u kojem su žene, kao spol koji ima vrednije reproduktivne resurse, češće preotimane i uspješnije u preotimanju partnera za kratkotrajne veze od muškaraca - spola s manje vrijednim reproduktivnim resursima.

Analize povezanosti između pojedinih aspekata preotimanja mogu upućivati na još neke procese koji omogućuju bolje razumijevanje ovoga fenomena. $U$ tom je smislu zanimljiva povezanost između učestalosti i uspješnosti preotimanja, dobivena i kod muškaraca i žena, a koja vjerojatno govori da se i kod preotimanja ponašamo u skladu sa zakonom efekta. I kod žena i kod muškaraca dobivena je relativno viso- 
DRUŠ. ISTRAŽ. ZAGREB GOD. 22 (2013), BR. 1 STR. 63-78

GRUNDLER, P., KARDUM I., HUDEK-KNEŽEVIĆ, J.: ÚČESTALOST NEKIH... ka povezanost između pokušaja da netko sudioniku preotme partnera i pokušaja da netko drugi preotme sudionika. S jedne strane, ta bi povezanost mogla biti posljedica toga što sudionici vlastitu sklonost da budu objektom preotimanja opravdavaju time što je i njihov partner bio objekt preotimanja, zatim, ona bi mogla biti posljedica toga što je u dobi u kojoj su bili sudionici ovog istraživanja preotimanje uobičajeno, a moglo bi se raditi i o tome da se partneri uparuju po sličnosti i kada se radi o sklonosti preotimanju. Treba napomenuti da su ovo samo pretpostavke na koje ovako provedeno istraživanje ne može dati valjane odgovore, ali koje bi mogle biti predmetom budućih istraživanja.

Rezultati ovoga istraživanja također pokazuju da su u vrijeme ispitivanja žene češće od muškaraca bile u ljubavnoj vezi i češće $u$ vezi s partnerom koji ih je privukao dok su bile $u$ vezi s nekim drugim. Kao što je dobro poznato, muškarci i žene razlikuju se u svojim psihološkim adaptacijama u izboru partnera za dugotrajnu vezu (Buss, 2007). Naime, muškarci veći naglasak stavljaju na znakove plodnosti i reproduktivne vrijednosti, kao što su ženina mladost i tjelesna privlačnost. Nasuprot tome, žene preferiraju karakteristike muškaraca, poput statusa, zrelosti, ambicioznosti i materijalnoga stanja znakova koji govore o njegovoj sposobnosti da ženu i njezino potomstvo kontinuirano opskrbljuje resursima. Dakle, žene, sudionice ovoga ispitivanja, na vrhuncu su svoje reproduktivne vrijednosti, pa su stoga poželjnije kao partneri za dugotrajnu vezu, dok je muškarcima potrebno još neko vrijeme da bi dosegli svoju maksimalnu vrijednost kao potencijalni partneri za dugotrajnu vezu. $S$ tim je povezana i intenzivnija intraspolna kompeticija muškaraca za seksualnim pristupom drugom spolu, pri čemu se oni služe raznim strategijama da bi privukli partnericu i odvratili od nje druge muškarce (Geary, 1998). Uzimajući u obzir navedene procese, nije neočekivano da su se žene češće $u$ vrijeme ispitivanja nalazile $u$ ljubavnoj vezi s muškarcem koji je njih privukao dok su bile u vezi s nekim drugim.

Zanimljivo je da od ukupno 96 sudionika koji su u ljubavnoj vezi s partnerom kojeg su privukli dok je bio u vezi s nekim drugim ili koji je njih privukao dok su bili u vezi s nekim drugim više od $90 \%$ svoje aktualne dugotrajne veze smatra dugotrajnima. Ovaj nalaz upućuje na to da je preotimanje partnera jedna od učinkovitih strategija za ostvarivanje dugotrajnih veza.

Kada se radi o efektima socioekonomskoga statusa na razne aspekte preotimanja partnera, rezultati su pokazali da su oni gotovo zanemarivi. To je vjerojatno posljedica dvaju međusobno povezanih razloga; činjenice da su sudionici bili vrlo homogeni s obzirom na socioekonomski status te upotreba re- 
DRUŠ. ISTRAŽ. ZAGREB GOD. 22 (2013), BR. 1, STR. 63-78

GRUNDLER, P., KARDUM I., HUDEK-KNEŽEVIĆ, J.: ÜČESTALOST NEKIH... lativno gruboga pokazatelja socioekonomskoga statusa kojim se nije moglo dobro razlikovati sudionike.

Treba napomenuti da se preotimanjem partnera ne ostvaruju samo reproduktivne prednosti nego ono može dovesti do niza adaptivnih problema. Tako npr. preotimanje može dovesti do osvete dotadašnjega partnera preotete osobe ili do narušavanja društvenog ugleda. Krajnje posljedice preotimanja mogu biti društvena izolacija, tjelesne ozljede ili čak smrt. Zbog toga bi u budućim istraživanjima preotimanje trebalo ispitivati unutar širega konteksta, odnosno usputnih adaptivnih problema koje ono može proizvesti.

Rezultati ovog istraživanja pokazali su da kod ispitanika obaju spolova postoji pozitivna povezanost socioseksualnosti s njihovim pokušajima preotimanja tuđih partnera i s pokušajima drugih da preotmu ispitanike. $U$ nešto manjoj mjeri socioseksualnost je povezana i s uspješnosti drugih da preotmu ispitanike, a samo kod muškaraca s pokušajima drugih da ispitanicima preotmu partnera. Općenito, rezultati pokazuju da je socioseksualnost relativno nisko povezana s iskustvima preotimanja, da su te povezanosti slične kod obaju spolova te da je socioseksualnost povezanija s pokušajima preotimanja nego s njihovom uspješnosti.

Relativno niska povezanost socioseksualnosti s iskustvima preotimanja mogla bi se objasniti širinom ovih dvaju konstrukata. Naime, socioseksualnost predstavlja opću sklonost dolaženja do većega broja partnera koja vjerojatno uključuje veći broj strategija, od kojih je jedna i preotimanje. Budući da preotimanje kao strategija dolaženja do partnera uključuje i rizike, moglo bi se pretpostaviti da je ona povezanija s onim interindividualnim razlikama koje predisponiraju osobe na rizičnija ponašanja, kao što su npr. crte tamne trijade (Jonason, Li i Buss, 2010). Ipak, u određenoj se mjeri i muškarci i žene više socioseksualnosti ponašaju prema drugim osobama kao da su im slične po socioseksualnosti, odnosno pretpostavljaju da će s njima lakše moći ostvariti kratkotrajnu seksualnu vezu, pa ih pokušavaju preoteti. Međutim, socioseksualnost sudionika nije povezana s njihovom uspješnosti preotimanja tuđih partnera nego samo s uspješnosti drugih da preotmu sudionike. Dakle, osobe visoke socioseksualnosti pokušavaju preoteti druge i odašilju signale koji drugima daju do znanja da su spremne biti preotete. To je u skladu s istraživanjima koja pokazuju da socioseksualnost drugih, a posebno muškaraca, procjenjujemo točnije od drugih crta, kao što su socijalna potencija, socijalna bliskost i stresne reakcije (Gangestad, Simpson, DiGeronimo i Biek, 1992). Nadalje, i žene i muškarci nerestriktivne socioseksualnosti $u$ razgovoru s nepoznatim privlačnim osobama suprotnoga spola iskazuju vidljiva neverbalna ponašanja koja signaliziraju njihovu seksualnu dostupnost (Simpson, Gangestad i Biek, 1993). 
DRUŠ. ISTRAŽ. ZAGREB GOD. 22 (2013), BR. 1 STR. $63-78$

GRUNDLER, P., KARDUM I., HUDEK-KNEŽEVIĆ, J.: ÚČESTALOST NEKIH...

\section{LITERATURA}

Iako su podaci ovoga istraživanja relevantni za uvid u raširenost ponašanja vezanih uz preotimanje partnera na studentskoj populaciji u Hrvatskoj, treba voditi računa i o nekim njegovim nedostacima. Jedan je od njih samoiskaz, odnosno subjektivna procjena kao način prikupljanja podataka. Naime, odgovori ispitanika o iskustvima preotimanja mogu biti neistiniti iz raznih razloga. Prije svega zbog socijalne (ne)poželjnosti preotimanja, ispitanici mogu namjerno ili nenamjerno davati iskrivljene odgovore. Nadalje, zbog razlike u reproduktivnim dobicima, muškarci i žene mogu na razne načine interpretirati čestinu ponašanja vezanih uz preotimanje. Tako npr. Davies, Shackelford i Hass (2007) navode da bi muškarci mogli biti skloniji razna afilijativna ponašanja žena interpretirati seksualno sugestivnima, dok bi žene mogle biti sklonije seksualno pristupajuća ponašanja muškaraca interpretirati prijateljskim ponašanjima.

Pitanja u upitniku otvaraju i mogućnost raznih interpretacija što je to uspješno preotimanje (npr. samo seksualni odnos ili ostvarenje dugotrajne veze). Nadalje, ovo istraživanje nije uzelo u obzir dužinu trajanja veza koje su nastale kao rezultat preotimanja, pa se ne zna koliko je bilo kratkotrajnih, a koliko dugotrajnih. U budućim bi istraživanjima primjenom drugih načina prikupljanja podataka (npr. detaljno intervjuiranje uspješnih otimača i preotetih), kao i heterogenijih uzoraka ispitanika (npr. s obzirom na dob, bračni status, broj djece, socioekonomski status te varijable kao što su predanost $u$ vezi iz koje je preoteta osoba, stupanj zadovoljstva postojećom vezom, kratkotrajnost/dugotrajnost veze itd.), trebalo osigurati bolji uvid $\mathrm{u}$ fenomen preotimanja i njegove distalne i proksimalne mehanizme.

Baker, R. R. i Bellis, M. A. (1995). Human sperm competition: Copulation, masturbation, and infidelity. London: Chapman and Hall.

Buss, D. M. (2002). Human mate guarding. Neuroendocrinology Letters Special Issue, 23, 24-29.

Buss, D. M. (2007). Evolutionary psychology: The new science of the mind. New York: Allyn \& Bacon.

Buss, D. M. i Schmidt, D. P. (1993). Sexual strategies theory: An evolutionary perspective on human mating. Psychological Review, 100(2), 204-232. doi:10.1037/0033-295X.100.2.204

Buss, D. M. i Shackelford, T. K. (1997). From vigilance to violence: Mate retention tactics in married couples. Journal of Personality and Social Psychology, 72(2), 346-361. doi:10.1037/0022-3514.72.2.346

Davies, A. P. C., Shackelford, T. K. i Hass, R. G. (2007). When a "poach" is not a poach: Re-defining human mate poaching and re-estimating its frequency. Archives of Sexual Behavior, 36(5), 702-716. doi:10.1007/s10508-006-9158-8 
DRUŠ. ISTRAŽ. ZAGREB GOD. 22 (2013), BR. 1, STR. 63-78

GRUNDLER, P., KARDUM I., HUDEK-KNEŽEVIĆ, J.: ÜČESTALOST NEKIH...
Ferguson, C. J. (2009). An effect size primer: A guide for clinicians and researchers. Professional Psychology: Research and Practice, 40(5), 532-538. doi:10.1037/a0015808

Foley, R. (1996). The adaptive legacy of human evolution: A search for the environment of evolutionary adaptedness. Evolutionary Anthropology, 5, 194-203.

Futuyma, D. J. (2009). Evolution. Sunderland: Sinauer Associates.

Gangestad, S. W. i Thornhill, R. (1997). Human sex selection and developmental stability. U J. A. Simpson i D. T. Kenrick (Ur.), Evolutionary social psychology (str. 169-195). Mahwah, NJ: Erlbaum.

Gangestad, S. W., Simpson, J. A., DiGeronimo, K. i Biek, M. (1992). Differential accuracy in person perception across traits: Examination of a functional hypothesis. Journal of Personality and Social Psychology, 62(4), 688-698. doi:10.1037/0022-3514.62.4.688

Geary, D. C. (1998). Male, female: The evolution of human sex differences. Washington, DC: American Psychological Association. doi:10.1037/ 10370-000

Jonason, P. K., Li, N. P. i Buss, D. M. (2010). The costs and benefits of the Dark Triad: Implications for mate poaching and mate retention tactics. Personality and Individual Differences, 48(4), 373-378. doi:10. 1016/j.paid.2009.11.003

Kardum, I., Gračanin, A. i Hudek-Knežević, J. (2006). Odnos crta ličnosti i stilova privrženosti s različitim aspektima socioseksualnosti kod žena i muškaraca. Psihologijske teme, 15, 101-128.

Kardum, I., Hudek-Knežević, J. i Gračanin, A. (2006). Sociosexuality and mate retention in romantic couples. Psihologijske teme, 15, 277-296.

Kenrick, D. T., Sadalla, E. K., Groth, G. i Trost, M. R. (1990). Evolution, traits, and the stages of human courtship: Qualifying the parental investment model. Journal of Personality, 58(1), 97-116. doi:10.1111/ j.1467-6494.1990.tb00909.x

Miller, G. F. i Todd, P. M. (1998). Mate choice turns cognitive. Trends in Cognitive Sciences, 2(5), 190-198. doi:10.1016/S1364-6613(98)01169-3

Platek, S. M. i Shackelford, T. K. (2006). Female infidelity and paternal uncertainty: Evolutionary perspectives on male anti-cuckoldry tactics. Cambridge: Cambridge University Press. doi:10.1017/CBO9780511617812

Schmitt, D. P. (2005). Sociosexuality from Argentina to Zimbabwe: A 48-nation study of sex, culture and strategies of human mating. Behavioral and Brain Sciences, 28(2), 247-311. doi:10.1017/S0140525X 05000051

Schmitt, D. P. i Buss, D. M. (2001). Human mate poaching: Tactics and temptations for infiltrating existing mateships. Journal of Personality and Social Psychology, 80(6), 894-917. doi:10.1037/0022-3514.80.6.894

Schmitt, D. P. i Shackelford, T. K. (2003). Nifty ways to leave your lover: The tactics people use to entice and disguise the process of human mate poaching. Personality and Social Psychology Bulletin, 29 (8), 1018-1035. doi:10.1177/0146167203253471

Schmitt, D. P. i sur. (2004). Patterns and universals of mate poaching across 53 nations: The effects of sex, culture, and personality on 
DRUŠ. ISTRAŽ. ZAGREB GOD. 22 (2013), BR. 1, STR. $63-78$

GRUNDLER, P., KARDUM I., HUDEK-KNEŽEVIĆ, J.: ÚČESTALOST NEKIH... romantically attracting another person's partner. Journal of Personality and Social Psychology, 86(4), 560-584. doi:10.1037/0022-3514.86.4.560

Simpson, J. A. i Gangestad, S. W. (1991). Individual differences in sociosexuality: Evidence for convergent and discriminant validity. Journal of Personality and Social Psychology, 60(6), 870-883. doi:10.1037/ 0022-3514.60.6.870

Simpson, J. A., Gangestad, S. W. i Biek, M. (1993). Personality and nonverbal social behavior: An ethological perspective of relationship initiation. Journal of Experimental Social Psychology, 29(5), 434 461. doi:10. 1006/jesp.1993.1020

Snyder, M., Simpson, J. A. i Gangestad, S. W. (1986). Personality and sexual relations. Journal of Personality and Social Psychology, 51(1), 181-190. doi:10.1037/0022-3514.51.1.181

Symons, D. (1979). The evolution of human sexuality. New York: Oxford University Press.

Trivers, R. L. (1972). Parental investment and sexual selection. U B. Campbell (Ur.), Sexual selection and the descent of man 1871-1971 (str. 136-179). Chicago, IL: Aldine.

Webster, G. D. i Bryan, A. (2007). Sociosexual attitudes and behaviors: Why two factors are better than one? Journal of Research in Personality, 41(4), 917-922. doi:10.1016/j.jrp.2006.08.007

Wiederman, M. W. (1997). Extramarital sex: Prevalence and correlates in a national survey. The Journal of Sex Research, 34(2), 167-174. doi:10. 1080/00224499709551881

\section{The Frequency of Some Aspects of Mate Poaching and Their Relationships with Sociosexuality}

\author{
Petra GRUNDLER \\ Faculty of Humanities and Social Sciences, Osijek \\ Igor KARDUM, Jasna HUDEK-KNEŽEVIĆ \\ Faculty of Humanities and Social Sciences, Rijeka
}

The aim of this study was to examine gender differences in attempts and successes of short-term poaching of someone else's sexual partner, the frequency of being a target of short-term poaching and the success of one's own short-term poaching attempts as well as the frequency of being a victim of short-term poaching of one's own sexual partner.

Furthermore, the relationships between different aspects of poaching experiences and sociosexuality in women and men were also examined. The study was carried out on a sample of 819 university students. The results showed that men attempted to poach someone else's sexual partner for a short-term relationship more often than women. A similar number of women and men reported to be somewhat 
DRUŠ. ISTRAŽ. ZAGREB GOD. 22 (2013), BR. 1, STR. $63-78$

GRUNDLER, P., KARDUM I., HUDEK-KNEŽEVIĆ, J.: ÜČESTALOST NEKIH... successful when poaching someone else's partner, but women more often than men reported to be quite successful. Furthermore, a similar number of women and men reported that someone tried to poach them for a short-term relationship. However, significantly more women reported to be a frequent target of poaching, while men reported that they were poached more easily than women. Women reported to have been more often than men in a romantic relationship and more often with a partner who had attracted them while they had been in another relationship. Sociosexuality is similarly related to different poaching experiences in women and men, and more with poaching attempts than with its success. The results obtained were explained by evolutionary theories of reproductive behavior.

Keywords: poaching, short-term relationship, sociosexuality, evolutionary theory 